\title{
Categorisation of Public Universities Funding
}

\author{
Abd Rahman Ahmad ${ }^{1}$, Alan Farley ${ }^{2} \&$ Ng Kim Soon ${ }^{1}$ \\ ${ }^{1}$ Faculty of Technology Management and Business, Universiti Tun Hussein Onn Malaysia, Malaysia \\ ${ }^{2}$ College of Business, Victoria University of Melbourne, Australia \\ Correspondence: Abd Rahman Ahmad, Faculty of Technology Management and Business, Universiti Tun \\ Hussein Onn Malaysia, 86400 Batu Pahat, Johor, Malaysia. Tel: 60-7-453-3952. E-mail: arahman@uthm.edu.my
}

Received: December 16, 2013 Accepted: March 6, 2014 Online Published: April 29, 2014

doi:10.5539/ass.v10n10p57 URL: http://dx.doi.org/10.5539/ass.v10n10p57

\begin{abstract}
This paper aims to investigate the impact of Federal Government policy on the categorisation of Malaysian public universities. The results of a quantitative survey questionnaire for major data collection and qualitative focus group interviews confirm that the initiative have an impact on research and teaching activities in Malaysian public universities. It can be concluded that the categorisation of Malaysian public universities play an important role in the development of research and teaching with greater focus on the university core functions. By utilising the results, the most important implications of this research relate to the practical aspects of the administration of public universities in Malaysia particularly during the government funding reforms. Finally, the researchers believe that the categorisation of Malaysian public universities is a rich and complex subject that offers many opportunities for future research including the comparative edge of Research/Apex Universities over other universities.
\end{abstract}

Keywords: university, categorisation, funding, research and development, teaching and learning

\section{Introduction}

Most countries around the world have begun to implement policies by categorising university into research and teaching aimed to concentrate the core functions (Brew, 2002; Marlin, 2009; OECD, 2010). Mohrman, Ma and Baker (2008) pointed out that the Research University (RU) facilitate to the social and economic development with the contribution of new knowledge to the society. In their review, the decision to establish RU has an impact to the increasing in operation cost, however it is requirement to compete at international level even with funding crisis. Funding mechanism and their impact on research and teaching however have shown different implications and effect (Ahmad, Farley, \& Naidoo, 2012; Diana, 2012). For the RUs, the key indicators of performance are the ability of the institutions to generate revenues from all sources. Therefore, the funding research strategy is desired objectives for the RU (Fernandez, 2011; Litwin, 2009).

Furthermore, Kongkiti et al. (2011) stated that the development of university classification model in Thailand based on performance indicators bring positive implication to the stakeholders. This is because the information provided through the information help the policy makers to manage higher education effectively to raise the targets for the university in Thailand. They further mention that the financial support for the teaching based university should not be the same with the research based university. The Malaysian Federal Government strategic plan intended to assist in transforming higher education in Malaysia to world-class status through executing a categorisation of Malaysian public universities into three groups: (1) Research/Apex Universities (RAUs); (2) Comprehensive Universities (CUs); and (3) Focused Universities (FUs).

\section{Literature Review}

Developing the education system has been an important priority in the national agenda in Malaysia since the nation gained independence in 1957. Successive Malaysian governments have stipulated many policies and initiatives to ensure that the national education system develops in line with the requirements of the national mission of producing first class human capital through education for the purpose of economic development (Kamogawa, 2003; Lee, 2000a; MoHE, 2007a). The government has stipulated that Higher Education Institutions (HEIs) have a special responsibility to promote social, economic and technological progress in the country. Universities are also expected to provide significant contributions to a high-income economy by producing graduates that have high competence and advanced skills to garner high-paying jobs in the market or 
produce innovative enterprises.

In order to move toward these goals, it is essential that the universities work more closely with the government, students, and other stakeholders to meet these challenges. As a result, the government has formulated many regulations, policies, and plans to foster the development of education system in Malaysia to monitor the higher education institutions behaviour according to its objectives and maintain a tight control over the advancement of higher education system (Lee, 2000b).

The first major initiative in education was taken by the government in 1962 when it established the first university in Malaysia known as University Malaya (UM) in 1962. In addition, the government is committed to make Malaysia a regional hub for higher education by ensuring excellence in service and reputation for quality (MoHE, 2007a). Indeed, this goal of making Malaysia an education hub was announced as the ultimate goal of Malaysian education policy by the former Prime Minister Tun Dr. Mahathir Mohamed, who saw that producing quality education was a key component in the larger plan to achieve the status of an industrialised and developed country by the year 2020 (Lee, 1999).

Recognising the importance of education in the overall national agenda, the Federal Government has taken many initiatives to transform the education system direction in line with the National Education Philosophy outlined in the Education Act 1996 (Parliament Malaysia, 1996). On 27 March 2004, the fifth Prime Minister of Malaysia, Tun Abdullah Bin Hj. Ahmad Badawi set up the Ministry of Higher Education (MoHE) to monitor the development of higher education so that it is consistent with the larger national agenda of becoming a centre of excellence for education and a fully developed nation by 2020 (Muniapan, 2008; Salleh, 2006; Sirat, 2010). Rashid (2000) explains that with world-class education the government means an education system that is able to spearhead the dynamic social change, progress in human development, rapid economic growth, improved living standards, social welfare, social reform and modernisation of society. More specifically the government seeks a quality education system that will impart in research excellence in science and technology and increase literacy rate in the broader society as it is stated in the National Higher Education Strategic Plan beyond 2020 and National Higher Education Plan 2007-2010.

Indeed, much of the process is already underway and there are many efforts to introduce positive transformation in higher education institutions across Malaysia. The features of traditional university (teaching, research, scholarship and innovation) in Malaysia are now being further expanded to meet the growing demand from the public. In line with the implementation of New Economic Model institutions of higher learning have become a major driving force that can propel new avenues in social and economic progress. Higher education institutions play a critical role in the success of New Economic Model implementation to boost national innovation and produce more activities in Research and Development (R\&D) (Abdullah, 2010).

\subsection{The Categorisation of Malaysian Public Universities}

Of the 20 universities in Malaysia, there are five RAUs, four CUs, and 11FUs. RAUs have a central function in the enhancement of R\&D, to discover new knowledge in different disciplines and promote other research-based T\&L activities in Malaysia (Mohrman et al., 2008). Because of the critical role of research excellence in quality education as well as innovative thinking leading to social and economic development, RUs do attract a lot of funding (Beerkens, 2010). Meanwhile, CUs and FUs deliver program at all levels from undergraduate, graduate and postgraduate but they have a different focus from RAUs because their core functions focus on T\&L excellence. The structure and category of public universities is shown in Table 1.

Table 1. The categorisation of Malaysian Public University

\begin{tabular}{|c|c|c|}
\hline Functions & Universities & Characteristics \\
\hline \multicolumn{3}{|l|}{ Research/Apex University } \\
\hline \multirow{5}{*}{$\begin{array}{l}\text { Focus on research activity and } \\
\text { learning based. }\end{array}$} & 1. Universiti Malaya (UM) & \multirow{5}{*}{$\begin{array}{l}\text { - Focused on research } \\
\text { - With highly competent academicians } \\
\text { - Competitive student admission } \\
\text { - Ratio of undergraduates to postgraduate } \\
\text { 50:50 } \\
\text { - Established universities }\end{array}$} \\
\hline & $\begin{array}{l}\text { 2. Universiti Kebangsaan Malaysia } \\
\text { (UKM) }\end{array}$ & \\
\hline & 3. Universiti Putra Malaysia (UPM) & \\
\hline & $\begin{array}{l}\text { 4. Universiti Sains Malaysia (USM) } \\
\text { (Apex University) }\end{array}$ & \\
\hline & $\begin{array}{l}\text { 5. Universiti Teknologi } \quad \text { Malaysia } \\
\text { (UTM) }\end{array}$ & \\
\hline Comprehensive University & & \\
\hline
\end{tabular}




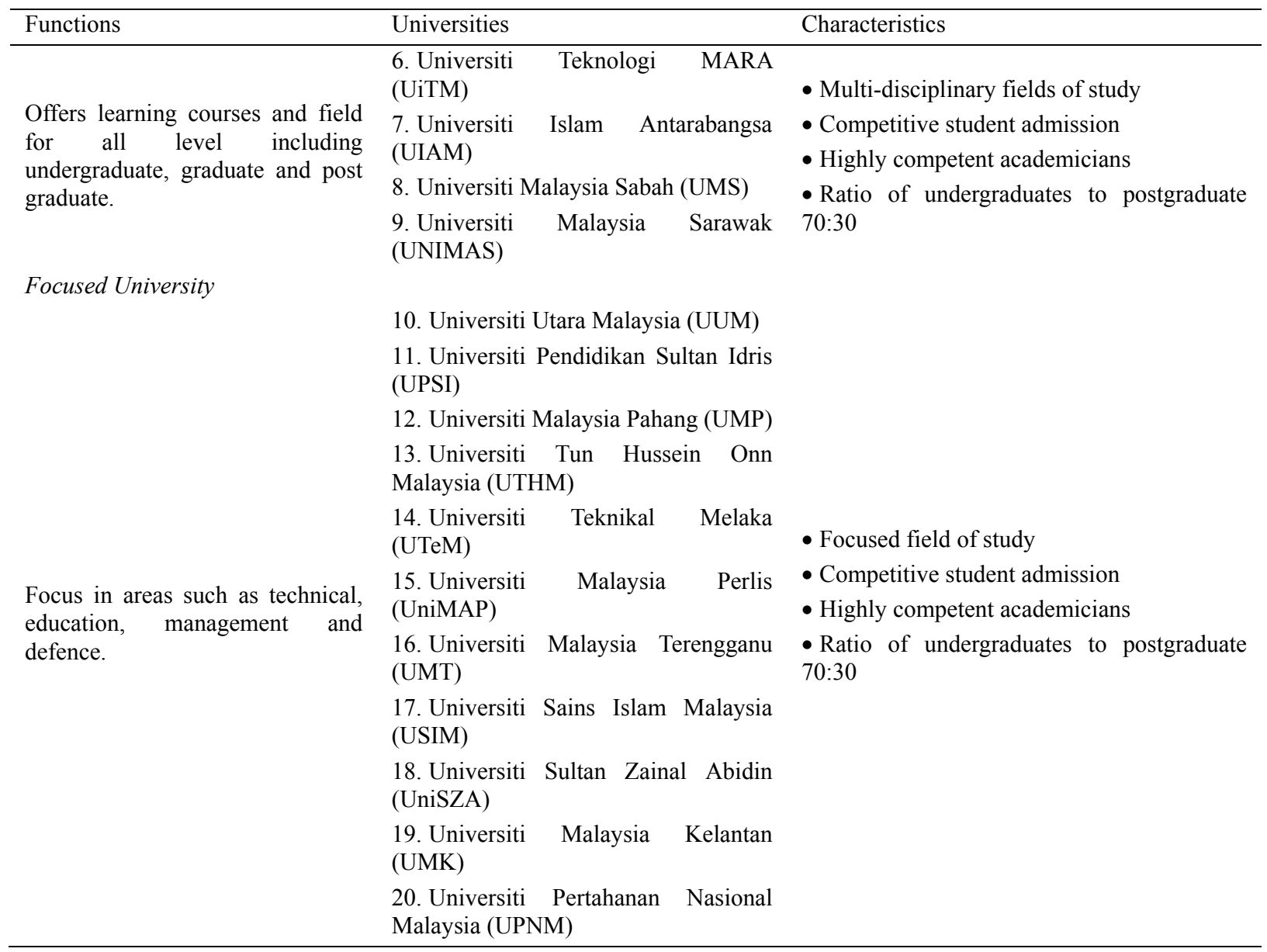

Source: MoHE (2007a \& 2007b)

The Minister for Higher Education Datuk Seri Mohamed Khaled Nordin in the press statement has extended the decision to maintain the status of USM, UM, UKM, and UPM as RAUs status for another three years where they will be put under strict assessment practice of the MyRA to determine whether they continue as RAUs (Lim, 2010). The decision was made on the basis of the audit which showed that the four RAUs had contributed to a significant increase in R\&D activities. Data indicated that the number of postgraduate students (human capital) had increased from 29,794 in 2007 to 39,819 in 2009, an increase of 10, 025 or 34 per cent. At the same time, the four varsities showed an increase of 89 per cent in publication in citation indexed journals from 2,303 in 2007 to 4,346 in 2009. Meanwhile, patent and intellectual property rights data shows an increase from 217 in 2007 to 237 in 2009, an increase of 9 per cent and finally the success of income generation showed a significant increase of RM310.7 million from RM436 million in 2007 to RM746.7 million in 2009 (Utusan Malaysia, 2010). The government has also provided additional funding of RM 153 million for R\&D activities as it recognised four new RAUs in the Ninth Malaysia Plan and one in Tenth Malaysian Plan (Azizan, 2007)

However, the pinnacle of institutional quality in Malaysia is the status of an Apex University. The government categorises an HEI to be an Apex University when it is deemed as being of the highest national standard in education and worthy of competition on the world stage (Khalid, 2008). The Federal Government has recognised USM as an Apex (Accelerated Programme for Excellence) University in 27 August 2008 (Morni, Talip, Bujang, \& Jusoff, 2009; Nordin, 2008).

The Apex University has the goals to: (1) drive world-class universities to K-Economy (research, design, and dissemination of knowledge, graduate/first-class human capital); (2) support the national goal of making Malaysia a hub for higher education; (3) act as a catalyst for the transformation of other institutions through best practice, collaborative research, academic, and policy improvements; and (4) promote competitiveness and drive for excellence (Razak \& Mohamed, 2011; MoHE, 2007a; Morni et al., 2009).

In addition to prestige and more monetary resources, Sirat (2008) has also found that an Apex University tends to 
have a decentralised financial system and more autonomy compared to other Malaysian public universities. Nevertheless, he adds that oftentimes greater autonomy in finance, student selection, setting tuition fees, management, and appointment of leadership positions is difficult to implement due to bureaucratic problems and government control.

\subsection{Malaysian Government Funding Reforms}

Government through the yearly budgets as well as lump-sum funding for development and capital expenditures (Country Report-Malaysia, 2008; Ismail \& Bakar, 2011). The government makes up for 90 per cent funding for all public HEIs and rest of the 10 per cent comes from students' fees (Lee, 2000a; MoHE, 2007b). A study from the World Bank indicated that the Malaysian government contributes quite a high proportion of its national income, about 2.7 per cent of its Gross Domestic Product (GDP) to education, compared to others OECD countries like Thailand 1.0 per cent, China 0.8 per cent and India 0.7 per cent (World Bank/EPU, 2007).

But in today's competitive market, the cost of providing higher education services is relatively high (Global University Network for Innovation, 2009; Jongbloed, 2000; Jongbloed \& Vossensteyn, 2001). Woodhall (2009) pointed out that there is a shift from government sources of funds to private funds in determining the cost sharing of higher education services in the world. Although, education levels are expected to rise, the trend over the world shows a common feature of declining levels of government support per student (Miller \& Salkind, 2002). In fact, the contribution of public expenditure on higher education per student as a percentage of GDP per capita in Malaysia has shown a decline from 116.6 per cent in 1990 to 71 per cent in 2006 (Tilak, 2008).

Sirat (2009) has argued that, this overall shift to self-funding and neo-liberalism is vital for public universities in Malaysia for confronting the pressures and changes in the global higher education landscape. However, according to Lee (200a), the Malaysian government still continues to provide the bulk of funding for Malaysian HEIs. The committee on the development and direction of higher education in Malaysia identified the higher education industry in Malaysia as a crucial site for strategic investment to improve the quality and quantity of Malaysian human capital (MoHE, 2006).

In line with the transformational planning of higher education, the Federal Government has allocated RM45.1 billion for the expenditure of education and training development. This plan also shows an increase in the budget for R\&D. The Ministry of Science, Technology, and Innovation (MoSTI) and MoHE are the main agencies that have the authority to provide funding for R\&D for HEIs. For the Ninth Plan period, an allocation of RM5.3 billion will be provided to increase the culture of R\&D in Malaysia. A more responsive planning has been announced by the Malaysian Prime Minister Dato' Seri Mohd. NajibTun Razak during tabling the Tenth Malaysian Plan on 10th June 2010.

According to Sirat and Kaur (2007) the categorisation of Malaysian public universities might be used as a platform to determine the funding that best fits their core functions. Because of the privilege and prestige attached to an RAU-status university, HEIs compete to gain this title. But the government uses a strict assessment tool called Malaysian Research Assessment Instrument (MyRA) to evaluate the performance of public universities in Malaysia (Yassin et al., 2011). The MyRA is administered by the MoHE to collect information from the HEIs and audited to access the universities performance in the areas outlined in the government objectives of the strategic plans. Here, four main parameters are used for the purpose of evaluation: (1) human capital; (2) publication; (3) paten and intellectual property rights; and (4) income generation.

The increasing number of public universities has also had some implications for funding allocation to the universities. Although, the general amount of the government budget for public universities in Ninth Malaysian Plan has increased, this amount is shared by the growing number of universities which then means that the actual amount received by each university is comparatively less (National Higher Education Research Institute, 2006). Furthermore, in the early stages of development, new universities need extra funding for operation and development compared to the established universities.

This study seeks to investigate the impact of Federal Government initiative on the categorisation of Malaysian public universities during the funding reforms with emphasis on $R \& D$ and $T \& L$.

\section{Methodology}

The mixed methods design in this study aims to integrate the advantages of both qualitative and quantitative approaches to enhance the accuracy of research findings (Bazeley, 2008; Creswell, 2003; Creswell \& Clark, 2007) and maximise reliability of the data (Kothari, 2005).

According to Yin (1994), qualitative methods are used to address questions of how and why in the investigations of a research. At the same time, quantitative methods are also associated with the answering of what and how 
questions. In accordance with this approach, this research design uses qualitative interviews for pilot testing, a quantitative survey for major data collection, and qualitative focus group interviews for enhanced understanding of the survey.

As this research design emphasises a combined mode of qualitative and quantitative methods, several data collection strategies are adopted. Firstly, in order to develop the survey instrument, interviews with the Director of National Higher Education Research Institute is undertaken. Here, the director of National Higher Education Research Institute has given positive feedback in supporting these interviews as a basis for developing the survey instrument. The first interview was employed as a basis for developing the survey questions and followed by the second interview aimed at confirming the survey instrument.

The next stage is to pilot the survey with an appropriate group including four potential respondents who are not involved with the people who assisted in formulating the survey instrument. Following this, the main survey questionnaire, to be distributed to all Malaysian public universities, was being written. This survey also includes closed questions using Likert scales to enable analysis of government funding changes on the research and teaching of Malaysian public universities. A typical scale includes a seven-point scale ranging to assess the situation before and after the funding reform proposed by the Malaysian Federal Government. This questionnaire was distributed to all twenty public universities in Malaysia. Next, the focus group interviews were conducted at four Malaysian public universities according to university category, with two from RAUs (one which has Apex status), one FU, and one CU.

\subsection{Data Analysis Strategies}

The Kruskal-Wallis test is a nonparametric test used in this study to examine the impact of changes in government funding on different types of Malaysian public universities (RAUs, CUs and FUs). In this study, it is used to compare the scores of continuous variables (university category) based on mean rank for each group in order to assess the differences in results from 2006, 2010 and 2015 (expected outcome). The presentation of results from the Apex University was combined with RU groups to be known as RAUs to protect the identity of the Apex University. Following this, the factorial ANOVA test of main effect is used to make comparisons across the subjects of multiple Independent Variables (IVs) on one Dependent Variable (DV). In order to run a factorial ANOVA, the researcher uses control variables to address the types of university category. Here, the intention is to look at the control variables in order to ascertain respondents' opinions, depending designation, length of time working in the designated position, and length of time working in universities. In addition, by controlling these variables, the researcher's main purpose is to address the main question by looking at differences according to university category. A five-way univariate ANOVA was executed with four independent groups $(4 \times 5 \times 4 \times 4)$. The normality test was not display because ANOVA is robust with the normality assumption size (Green \& Salkind, 2008; Montgomery, 2005).

In order to get in-depth information from quantitative analysis, data from the focus group interviews are analysed. In this research, the focus group interviews were conducted in the English language, and recording were transcribed and coded to identify themes and meanings. Thus, findings from this process help to identify patterns that are associated with each variable among respondents in the different categories of Malaysian public universities. The goal was to integrate the themes and meanings to assist the researcher in determining the relationships between variables. The strategies used to collect and analyse the data from focus group interviews, as proposed by Miles and Huberman (1994) include: data collection, data reduction, data display, and conclusion.

\section{Findings}

\subsection{Demographic Analysis from Survey Questionnaires}

Of the 120 respondents, 52 participants $(43.3 \%)$ were from the FU groups. This category was followed by respondents from the RAU groups (42.4\%). Additionally, 27 participants $(22.5 \%)$ were from CU groups. Furthermore, most respondents participating in this study held positions as Dean (67.5\%), and Deputy Vice Chancellors/Deputy Rectors (16.7\%). Approximately 7.5 per cent of the respondents were Heads of Bursar Offices or equivalent. Finally only two respondents $(1.7 \%)$ were Vice Chancellors.

The majority of respondents (40.0\%) reported having two to four years working experience in their designated positions with 37 or $(30.8 \%)$ reporting less than two years working experiences, and 28 respondents $(23.3 \%)$ reported five to seven years of time working in their designated position. Only seven (5.8\%) had more than seven years working experience. Indeed, more than half of the respondents $(60.8 \%)$ had being serving in universities for more than twenty years. These was followed by those with eleven to twenty years of services $(32.5 \%)$ and about less than 10 per cent of respondents have been working in universities between five to ten years. 


\subsection{The Results of $R \& D$}

Table 2. Results of the Kruskal-Wallis test for R\&D

\begin{tabular}{lllllll}
\hline \multirow{2}{*}{ University Category } & 2006 & & 2010 & & 2015 & \\
\cline { 2 - 7 } & Mean rank & Sig & Mean rank & sig & Mean rank & sig \\
\hline RAU & 82.11 & .000 & 86.20 & .000 & 85.15 & .000 \\
RAU & 81.24 & & 91.60 & & 89.02 & \\
CU & 41.33 & & 37.42 & & 37.44 & \\
FU & 40.60 & & 43.57 & & 46.66 & \\
\hline
\end{tabular}

$\mathrm{p}<.05$ level of significance

$R \& D$ : As indicated in Table 2 the Kruskal-Wallis test yields a p-value of 0.000 , which is highly significant in $2006\left[\mathrm{x}^{2}(3, \mathrm{~N}=109)=40.97, \mathrm{p}=0.000\right], 2010\left[\mathrm{x}^{2}(3, \mathrm{~N}=115)=56.00, \mathrm{p}=0.000\right]$ and $2015\left[\mathrm{x}^{2}(3, \mathrm{~N}=116)=\right.$ $46.77, \mathrm{p}=0.000]$. Further, by observing the mean ranks of the university category, the RAU groups have the highest scores and FU and CU groups has the lowest score. Next, the factorial ANOVA was performed to analyse the differences between university groups.

Table 3. Results of the factorial ANOVA for R\&D

\begin{tabular}{ll}
\hline Year & University Category \\
\hline 2006 & $\mathrm{~F}(3,96)=25.05, \mathrm{p}<0.0005^{1}$ \\
2010 & $\mathrm{~F}(3,102)=38.44, \mathrm{p}<0.0005^{1}$ \\
2015 & $\mathrm{~F}(3,103)=29.64, \mathrm{p}<0.0005^{1}$ \\
\hline
\end{tabular}

$\mathrm{p}<.05$ level of significance

${ }^{1}$ Stastically significant main effects

The results obtained from the Levene's test of variances show no significant difference across the groups for each of the time periods in 2006, 2010 and 2015, and therefore met the homogeneity of variances assumption. Table 3 presents the results from the test for between-subjects effects based on the average score. The results show a significant difference main effect is confirmed in $2006, F(3,96)=23.52, \mathrm{p}<0.0005 ; 2010, F(3,102)=$ $38.45, \mathrm{p}<0.0005$; and $2015, F(3,103)=29.64, \mathrm{p}<0.0005$. Following this, the post hoc comparisons using the Tukey HSD test was conducted when main effects were found to be statistically significant in order to determine the source of the university groups' differences. The post hoc test results show that significant differences were found in R\&D activities for RAU with CU and FU groups in 2006, 2010 and 2015 (expected outcome). The present results also showed that the RAU groups mean score differs significantly from CU and FU groups according to period of time. The results obtained support the objective of the study, as a difference reporting varies across the Malaysian public universities sector.

\subsection{The Results of $T \& L$}

Table 4 shows the results of the statistical analysis based on the average scores for T\&L for each time period that were significantly different in $2006, \mathrm{x}^{2}(3, \mathrm{~N}=114)=35.43, \mathrm{p}=0.000 ; 2010, \mathrm{x}^{2}(3, \mathrm{~N}=118)=35.58, \mathrm{p}=0.000$; and $2015, \mathrm{x}^{2}(3, \mathrm{~N}=118)=6.59, \mathrm{p}=0.000$. In other words, there is at least one pair of university categories that have a different average score.

Table 4. Results of the Kruskal-Wallis test for T\&L

\begin{tabular}{lllllll}
\hline \multirow{2}{*}{ University Category } & 2006 & & 2010 & & 2015 \\
& Mean rank & Sig & Mean rank & sig & Mean rank & sig \\
\hline RAU & 76.95 & .000 & 78.00 & .000 & 76.44 & .000 \\
RAU & 82.05 & & 86.61 & & 68.15 & \\
CU & 56.46 & & 52.37 & & 57.57 & \\
FU & 39.03 & & 42.84 & & 52.27 \\
\hline
\end{tabular}

$\mathrm{p}<.05$ level of significance 
The mean rank for RAU groups is significantly higher compared to CUs and FUs at 2006, 2010 and 2015 (expected outcome). As indicated, there is a significant increase in the mean rank for CU and FU groups from 2006 to 2015 (expected outcome). The results indicated in the table below were then further explored using the factorial ANOVA test.

Table 5. Results of the factorial ANOVA for T\&L

\begin{tabular}{ll}
\hline Year & University Category \\
\hline 2006 & $\mathrm{~F}(3,101)=19.85, \mathrm{p}<0.0005^{1}$ \\
2010 & $\mathrm{~F}(3,105)=19.89, \mathrm{p}<0.0005^{1}$ \\
2015 & $\mathrm{~F}(3,105)=3.20, \mathrm{p}<0.05^{1}$ \\
\hline
\end{tabular}

$p<.05$ level of significance

${ }^{1}$ Stastically significant main effects

The test of between-subjects effects indicated that there were significant main effects in $2006 F(3,101)=19.85$, $\mathrm{p}<0.0005 ; 2010, F(3,105)=19.89, \mathrm{p}<0.0005$; and 2015 expected outcome $F(3,105)=3.20, \mathrm{p}<0.05$ with regard to the government funding changes that altered the approach to T\&L. Furthermore, the results of post hoc comparisons analysis confirmed that the mean score on T\&L activities for RAUs $(M=4.08)$ were significantly different from FU groups $(\mathrm{M}=2.80)$ in 2006. The mean score were also reported significant for RAU groups with CU and FU groups in 2006 and 2010. However, no other significant difference was found in 2015 expected outcome. The results obtained support the objective of the study, as a difference reporting varies across the Malaysian public universities sector in 2006 and 2010.

\subsection{Results from Qualitative Focus Group Interviews}

Participants in the focus group interviews pointed out that the categorisation of public universities in Malaysia plays an important role in the development of R\&D because the core functions of universities have changed and $\mathrm{R} \& \mathrm{D}$ is now accorded greater importance in the categorisation system. In the new funding reform the core function of RAUs is now focused on R\&D activities compared to CUs and FUs, which still consider T\&L as a major activity. Participants from the RAU status university justified these changes saying that the government wanted to use the best resources available needed for wealth creation and capitalising on R\&D was the best option to do so. With the additional funding and resources provided, they are expected to meet the key performance indicators targeted in MyRA or otherwise their status is forfeited.

Results in this study revealed that CUs and FUs felt comparatively less pressure to excel in R\&D activities because of they were involved in other educational activities besides research. In addition, most of the CUs and FUs are relatively new and these universities did not have a previous history with which they could measure the impact of current changes in government policy to measure any differences. On the other hand, universities with the RAU status having been established for a long time have worked under different government policy regimes and also have sufficient expertise to work in research to feel the pressure of current demand from the government to improve university research.

In contrast, universities with CUs and FUs status still needed to have R\&D activities even without any additional funding for research. However, with the funding constraints, these categories of universities are now focusing more on T\&L. Participants from the CU and FU expanded upon some of the limitations they faced in excelling in research.

The data revealed that the categorisation of public universities does play an important role in the development of T\&L activities. These results can be further confirmed by the feedback from participants in the focus group interviews. Participants at the RAU stated that although they have acquired the RAU status with its research-focused agenda, T\&L remains a core function and the university will not compromise on the quality of T\&L.

Data from this study revealed that RAUs are now focusing on smaller number of undergraduates and larger number of postgraduate programs and students. Doing this seems to have emerged as an efficient way to promote research culture and maintain a balance between R\&D and T\&L. By lessening focus on undergraduate classes and encouraging more advanced, independent study-based postgraduate classes, they could still maintain their commitment to T\&L without hampering research. 
It seems that FUs and CUs are also working to increase the number of seats and degrees offered at the postgraduate level. However, for the time being, with their present status as teaching-oriented universities FUs and CUs need to take in more undergraduate students. It is also interesting to note that FUs are now required by the government to increase the number of students at the diploma level due to recent changes in government policy.

The evidence in this study indicates that nearly all participants were agreed that the categorisation of public universities in Malaysia might be used as one of the yardsticks to determine the type of funding that best fits with their core functions. Categorisation of public universities more or less help the government determine the allocation of resources and resource planning based on university strengths. Using this approach, the government can allocate their limited resources to the different universities according to their niche areas. In contrast to the above statements, University D (FU status) felt that the while categorisation played an important role in funding allocation, the policy has a negative impact on them because the funding was more research-oriented and the mechanism monitoring university performance being the same for all university categories, it ignored a university's achievement in T\&L.

\section{Discussion}

This study has found that the R\&D and T\&L implemented vary across Malaysian public universities. Here, the RAU status granted to five universities has led to significant improvement in their performance with these universities leading to more income generation in their R\&D, and T\&L activities. One significant aspect of these funding reforms has been a focus on R\&D with greater incentives provided by the government to promote a research culture in Malaysian universities. RAUs have been the greatest beneficiary of these reforms as they receive greater funding in comparison to other universities for their research activities (MoHE, 2007b). However, while their status as a research-focussed HEI may give these institutions greater access to funds, the government constantly measures whether the RAUs are maintaining their standards of research activities. After being initially recognised as an RAU, the performance of an HEI in research activities is carefully monitored and the RAU status is extended for another three more years after the strict evaluation process using the MyRA system (Lim, 2010).

Moreover, participants from CUs and FUs also confirmed that the T\&L and R\&D activities at their institutions are also being audited more frequently by the government. Although the results confirmed that the CUs and FUs are focused on T\&L activities, they have showed greater involvement in some activities such as enrolling postgraduate students, running postgraduate programs, and international students, which are normally under the jurisdiction of the RAUs. The results prove that the quality of T\&L remains a big priority in the FUs and CUs despite the funding constraints and it appears that these universities are able to provide $T \& L$ with the same standards as the RAUs.

Thus, findings in this study have found that the objectives of categorisation of public universities can be used by the government to allocate funding on the basis of the area of specialisation in the universities according to their past records and established strengths. It was also found that RAUs are able to generate more income produced by the R\&D activities compared to CUs and FUs. Indeed, it is suggested that the government must take several aspects of the strengths and weaknesses of a university into account before implementing the funding system. This finding is consistent with the study from Sirat and Kaur (2007).

The results obtained from quantitative survey questionnaire and qualitative focus group interviews were very significant and validated the overall positive impact of the funding reforms on public universities in Malaysia. This means that the funding reforms have altered the approach taken with regards to $T \& L$ and $R \& D$ in public universities in Malaysia. Although the government needs to consider some issues such as the difference in resources between RAUs and other universities, difficulty of commercialising research etc., the overall thrust of the funding reforms has led to some positive change, as evidence in the good feedback from the participants in the focus group interviews. On the whole public universities seem to have embraced the changes brought about by the funding reforms. In spite of the obstacles in the way of the implementation of National Higher Education Strategic Plan beyond 2020 and National Higher Education Plan 2007-2010, the majority of the participants viewed these reforms as necessary interventions for improving the standard of higher education and displayed a positive and optimistic attitude emphasising that the changes were challenges to be tackled rather than difficulties to be shunned.

\section{Conclusion}

This study generates useful information for the Malaysian Federal Government and its agencies to understand how these funding reforms have contributed to the achievement of their objectives and make necessary adjustments to improve their policies. Findings indicate that the funding changes have had a positive impact on the government objectives, however, there are several areas that the MoHE needs to consider while 
implementing such funding reforms. The government needs to pay more attention to the logistical difficulties that new universities are facing in implementing the government strategic plans. Moreover, it is advised that the government allocate more autonomy to the public universities so that they can better pursue the desired outcomes. Indeed, the autonomy implemented must be followed with the policies that guide the university to behave accordance to the government aspirations. The findings of this study can also be helpful for governments in other countries, especially developing countries, when they are deliberating about the appropriate design of university funding reform that best fit their political, economic and social environment.

Further research is necessary to study the impact of government funding changes on specific areas of operations in Malaysian public universities. In order to obtain a clearer, more detailed picture of the impact of funding reforms on each of these areas, it is suggested that future research be conducted with an in-depth individualised focus on each of these areas. In particular, the researchers believe that the categorisation of Malaysian public universities is a rich and complex subject that offers many opportunities for future research. This research has discovered an array of issues, including the comparative edge of RAUs over other universities and the complexity of distributing funding according to university status, which can be further analysed by focusing on the impact of funding reforms and categorisation of universities.

\section{Acknowledgements}

The authors would like to thank the Universiti Tun Hussein Onn Malaysia and Ministry of Education Malaysia for supporting this research under the Exploratory Research Grant Scheme (ERGS). In addition the authors also to thank the respondents that give full support in this research.

\section{References}

Abdullah, S. C. (2010, April 30). Inovasi IPT mampu jayakan MEB. Berita Harian.

Ahmad, A. R., Farley, A., \& Naidoo, M. (2012). Impact of the government funding reforms on the teaching and learning of Malaysian public universities. Higher Education Studies, 2(2), 114. http://dx.doi.org/10.5539/hes.v2n2p114

Azizan, H. (2007, November 18). Ready for the big leap, The Star.

Bazeley, P. (2008). Mixed method in management research. The SAGE dictionary of qualitative management research, 133-136. London: Sage.

Beerkens, E. (2010). Global models for the national research university: Adoption and adaptation in Indonesia and Malaysia. Globalisation, Societies and Education, 8(3), 369-391. http://dx.doi.org/10.1080/14767724.2010.505099

Brew, A. (2002). Enhancing the quality of learning through research-led teaching. Paper presented at the HERDSA 2002 Conference, Perth, Australia.

Country Report-Malaysia. (2008). Facing global and local challenges: The new dynamics for higher education. Paper presented at the Asia Pasific sub-regional preparatory conference for the 2009 world conference on higher education, Macao SAR, PR China.

Creswell, J. W. (2003). Research design: Qualitative, quantitative, and mixed methods approaches (2nd ed.). United States: Sage publication.

Creswell, J. W., \& Clark, V. L. P. (2007). Designing and conducting mixed methods research. United States of America: Sage Publications.

Diana, H. (2012). Performance-based university research funding systems. Procedia Social and Behavioral Sciences, 41(2), 251.

Fernandez, K. (2011). The Revenue Imperative: Finding New Funding Streams in the Face of Budget Cuts. Community College Journal, 81(4), 26-29.

Global University Network for Innovation. (2009). Higher education at a time of transformation: New dynamics for social responsibility. Basingstoke: GUNI/Palgrave Macmillan.

Green, S. B., \& Salkind, N. J. (2008). Using SPSS for Windows and Macintosh: Analyzing and understanding data. Upper Saddle River, N.J: Pearson/Prentice Hall.

Ismail, S., \& Abu Bakar, N. B. (2011). Reporting practices of Malaysian public universities: The extent of accountability disclosur. African Journal of Business Management, 5(15).

Jongbloed, B. (2000). The funding of higher education in developing countries. Management \& Policy in Higher 
Education, 32, 13-42.

Jongbloed, B., \& Vossensteyn, H. (2001). Keeping up performances: An international survey of performance-based funding in higher education. Journal of Higher Education Policy \& Management, 23(2), 127-145. http://dx.doi.org/10.1080/13600800120088625

Kamogawa, A. (2003). Higher education reform: Challenges towards a knowledge society in Malaysia. African \& Asian Studies, 2(4), 545-563. http://dx.doi.org/10.1163/156920903773004059

Kongkiti, P., Suphattra, K., Jayanthi, R., \& Binshan, L. (2011). Developing a university classification model from performance indicators. Performance Measurement and Metrics, 12(3), 183-213. http://dx.doi.org/10.1108/14678041111196668

Kothari, C. (2005). Research Methodology: Methods \& Techniques. New Delhi: New Age International.

Lee, M. (1999). Education in Malaysia: Towards Vision 2020. School Effectiveness \& School Improvement, 10(1), 86-98. http://dx.doi.org/10.1076/sesi.10.1.86.3514

Lee, M. (2000a). The impacts of globalization on education in Malaysia. In N. P. Stromquist, \& K. Monkman (Eds.), Globalization and education: Integration and contestation across cultures (pp. 315-332). Lanham, MD: Rowman \& Littlefield.

Lee, M. (2000b). Expanding the state role in Malaysian higher education. Paper presented at the International Higher Education.

Lim, R. (2010, July 25). Research uni status extended, Sunday Star.

Litwin, J. M. (2009). The efficacy of strategy in the competition for research funding in higher education. Tertiary Education and Management, 15(1), 63-77. http://dx.doi.org/10.1080/13583880802700131

Marlin, C. (2009). Focusing research in universities. Perspectives: Policy and Practice in Higher Education, 13(2), 42-47. http://dx.doi.org/10.1080/13603100902805458

Miles, M. B., \& Huberman, M. A. (1994). Qualitative data analysis: An expanded sourcebook (2nd ed.). Beverley Hills: Sage.

Miller, D., \& Salkind, N. (2002). Handbook of research design \& social measurement. Thousand Oaks, Calif: Sage Publications.

MoHE. (2006). The report by the committee to study, review and make recommendations concerning the development and direction of higher education in Malaysia: Ministry of Higher Education.

MoHE. (2007a). In M. o. H. Education (Ed.), National higher education action plan 2007-2010. Putrajaya.

MoHE. (2007b). Pelan strategik pengajian tinggi negara melangkau tahun 2020. Putrajaya.

Mohrman, K., Ma, W., \& Baker, D. (2008). The research university in transition: The emerging global model. Higher Education Policy, 21(1), 5-27. http://dx.doi.org/10.1057/palgrave.hep.8300175

Montgomery, D. C. (2005). Design and analysis of experiments. Hoboken: Wiley.

Morni, F., Talip, M. S. A., Bujang, F., \& Jusoff, K. (2009). APEX University: Is it the Malaysian way forward? Paper presented at the Computer Technology and Development 2009 International Conference, Kota Kinabalu, Malaysia. http://dx.doi.org/10.1109/ICCTD.2009.175

Muniapan, B. (2008). Perspectives and reflections on management education in Malaysia. International Journal of Management in Education, 2(1), 77-87. http://dx.doi.org/10.1504/IJMIE.2008.016232

National Higher Education Research Institute. (2006). Laporan model universiti untuk Malaysia. Pulau Pinang: Universiti Sains Malaysia.

Nordin, M. K. (2008). Mengubah senario global dalam pendidikan tinggi. Paper presented at the Seminar pengurusan akademik IPT 2008, Langkawi, Malaysia.

OECD. (2010). Performance-based funding for public research in tertiary education institutions: Workshop proceedings. Paris: Organization for Economic Cooperation and Development (OECD).

Parliament Malaysia. (1996). Education Act 1996 Kuala Lumpur: Government Printer.

Rashid, A. R. A. (2000). Wawasan dan agenda pendidikan. Kuala Lumpur: Utusan Publication \& Distributors Sdn Bhd.

Razak, D. A., \& Mohamed, R. (Eds.). (2011). Transforming higher education for a sustainable tomorrow: 
Laying the foundation. Pulau Pinang: Universiti Sains Malaysia.

Salleh, S. M. (2006). Koleksi ucapan Menteri Pengajian Tinggi (27 March 2004 hingga 13 February2006). Putrajaya: Kementerian Pengajian Tinggi.

Sirat, M. (2008). Review of higher education institutions in regional development: The OECD programme on institutional management in higher education and directorate for public governance and territorial development. Penang, Malaysia.

Sirat, M. (2010). Strategic planning directions of Malaysia higher education: University autonomy in the midst of political uncertainties. Springer Science Business Media, 4, 461-473.

Sirat, M., \& Kaur, S. (2007). Financing higher education: Mapping public funding options. Updates on Global Higher Education, (12). Retrieved from http://www.ipptn.usm.my/v2/index.php/publication/cat_view /20-global-updates/38-global-updates-2007.html

Tilak, J. (2008). Higher education: A public good or a commodity for trade? Prospects, 38(4), 449-466. http://dx.doi.org/10.1007/s11125-009-9093-2

Utusan Malaysia. (2010, July 30). Pencapaian universiti penyelidikan membanggakan. Utusan Malaysia.

Woodhall, M. (2009). Financing higher education: The role of tuition fees and student support Higher education in the world 2006: The financing of universities/Global University Network for Innovation London: Basingstoke. Hampshire: Palgrave Macmillan.

Yassin, I. M., Zabidi, A., Johari, M. A., Hijaz, F., Izzudin, A. H. Y., Tahir, N. M., ... Majeed, A. B. A. (2011). Entity-Relationship analysis for development of Malaysian University Research Assessment Instrument (MyRA) information system. Paper presented at the System Engineering and Technology (ICSET), 2011 IEEE International Conference, Shah Alam, Malaysia. http://dx.doi.org/10.1109/ICSEngT.2011.5993454

Yin, R. K. (1994). Case study research: Design and methods (2nd ed.). Thousand Oaks: Sage Publications.

\section{Copyrights}

Copyright for this article is retained by the author(s), with first publication rights granted to the journal.

This is an open-access article distributed under the terms and conditions of the Creative Commons Attribution license (http://creativecommons.org/licenses/by/3.0/). 